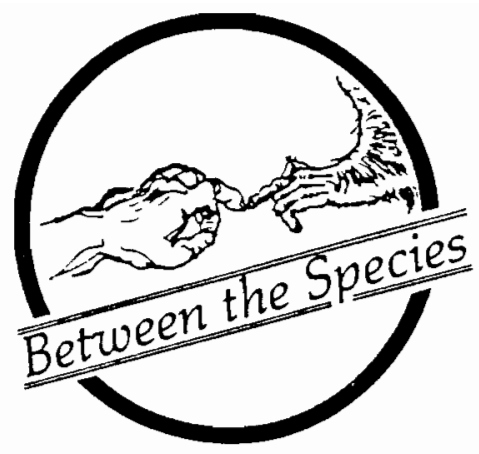

\title{
BARAD, AQUINAS, AND "FROM-TO" PERSPECTIVE
}

\section{Daniel Dombrowski} Seattle University

\section{Editors' Note:}

Professor Dombrowski's essay was presented at the December, 1988 Eastern Division meeting of the Society for the Study of Ethics and Animals (held in Washington, D.C.) as a response to a paper delivered by Professor Judith Barad, of Indiana State University, and entitled 'Aquinas' Inconsistency on the Nature and the Treatment of Animals.' Professor Barad's essay was published in the Spring, 1988 issue of Between the Species (Vol. 4, no. 2).

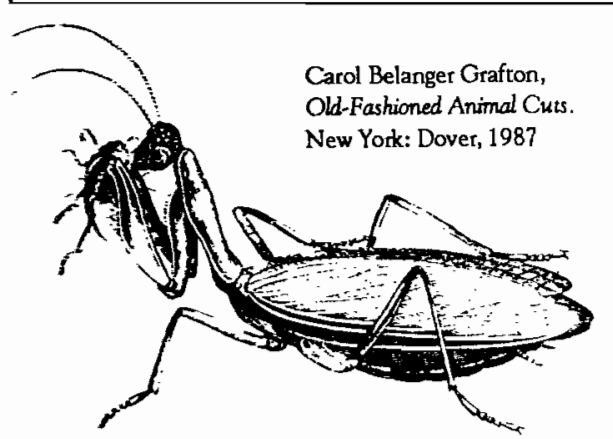

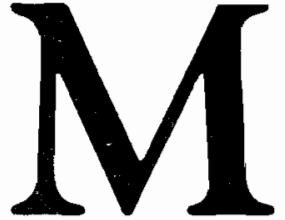

$y$ purpose in this article is to comment favorably on a recent article by Judith Barad, an article which claimed that Thomas Aquinas was not a speciesist without qualification because he had an inconsistent attitude toward animals. That is, Aquinas should have had a more favorable attitude toward animals than he apparently did because of some principles which were fundamental to his own thought. My comments will lead to some rather broad speculations regarding how we should view the history of thought on animals.

Barad's article does not leave the taste one gets from that type of history of philosophy which returns to the past purely for the sake of

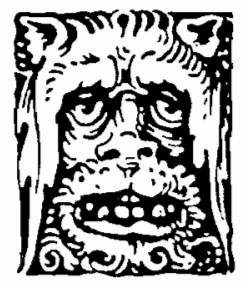

PHLOSOPHY 
antiquarian lore, as would have been the case if she found out what Aquinas said about animals merely to fill one more niche in the historian's edifice, so that all topics in all philosophers would be commented on. She avoids another evil. That is, doing rancid violence to a past thinker through a crude (usually anachronistic) appropriation of him for the purposes of present philosophizing. It should be noted, however, that at times it is quite legitimate to lean in this direction, as in the half-informed whipping and gnashing Descartes has received by defenders of animal rights. The legitimacy of these polemical uses of Descartes becomes apparent when we read John Cottingham's well-informed, nuanced, and nonetheless unconvincing attempt to make Descartes' view of animals more palatable. ${ }^{1}$

It is difficult for us to tell whether it is Barad's philosophical sources which are being interpreted or if it is her interpretive efforts which are being textually grounded. Historical objectivity increases along with this difficulty.

But perhaps the most complimentary thing I can say about Barad's article is that it made me think seriously about some of the biggest issues regarding the history of the philosophic treatment of animals, and, I confess, it made me revise some of my own views of that history. Specifically, as a consequence of Barad's article 1 think we should get clear on how our "from-to" perspective operates in the history of the philosophic treatment of animals and how our choice of such a perspective affects how we will digest the thought of a particular thinker or of a particular historical period. To take a preliminary example from outside the philosophic treatment of animals, consider how one's approach to Kant's epistemology is affected not so much by which contemporary method- ology one uses to study Kant but by the fact that in the Anglo-American philosophical world Kant is usually studied as the culmination of the period from Descartes and Locke, whereas in Germany he is more often studied as the start of a period which ends with Hegel and Marx. This "mere" change in from-to perspective to some extent, at least, changes one's view of Kant.2

Regarding the history of philosophic thought on animals 1 , at least, have focused on the following from-to perspective: from Pythagoras to Plotinus there were many thinkers who showed profound respect for animals, among them Pythagoras and Plotinus themselves, as well as Plato, Theophrastus, Plutarch, and Porphyry. At the end of the classical period, however, the favorable treatment of animals died out, for the most part, among philosophers until the nineteenth century. On the assumption that focusing on this from-to perspective gave the best vision of the past, the period from Aquinas to Descartes appeared to be one where the bad got worse, in that Descartes was, as Peter Singer puts it, the absolute nadir, Cottingham's efforts to the contrary not withstanding. A corollary of this from-to perspective was that one could easily understand the movement from Descartes to LaMettrie to factory farming and vivisection with equanimity. That is, Descartes' view of animals as mere machines made it possible to view animals as commodities and mere objects for pithing. And Descartes' view of human beings as machines with mere ghosts in them led, as Leonora Rosenfield has shown, ${ }^{3}$ to LaMettrie's (not to mention Ryle's) rather convenient exorcism of the ghosts.

As a consequence of Barad's article, however, we are forced to re-focus our historical lenses when we look at the transition from 
Aquinas' (and Francis of Assisi's) thirteenth century to Descartes' seventeenth. Indeed, there is hardly a transition here at all, but rather a radical break. Because of Barad's article we are forced to ask: how does one get from Aquinas to Descartes? Both were anthropocentrists, but Aquinas' epistemology, psychology, and his Lovejoy-like great-chain-ofbeing metaphysics militate against his anthropocentrism - hence Barad's charge of inconsistency. Descartes is frustrating because he is so consistent. He views animals as machines, and there is very little, if anything, in his thought to indicate that he should have held otherwise.

Might it be the case that all of the major pre-modern philosophers are either morally sympathetic to animals or are thinkers whose lack of moral sympathy with animals conflicts with claims that are central to these thinkers' philosophies? This is a broad claim, but consider that the two major pre-modern opponents to what we today would call "animal rights" were Aristotle and Aquinas. The former's greatest pupil and literary executor, Theophrastus, made us aware of Aristotle's inconsistency regarding animals, 4 and now a similar argument regarding Aquinas' inconsistency is offered by Barad.

If this broad claim is correct, or at least largely correct, one can easily imagine two reasons why it is so. First, almost all of the pre-modern philosophers believed in, or flirted with, either panpsychism or hylomorphism, positions which, it seems, are far more compatible with care for nonhuman nature than either Cartesian dualism (which sees most of nature as amenable for enslavement, with a few scattered minds strewn about as exceptions to the rule) or Cartesian dualism's assumed alternative in modern or contemporary philosophy, some sort of materialistic or mechanistic monism (in which one has the difficult project of justifying respect for anything, even respect for human beings ${ }^{5}$ ).

That is, in the effort to explain the apparent differences between mental phenomena and terms, on the one hand, and bodily phe-

\section{Night it be the case that \\ D all of the major pre-} modern philosophers are either morally sympathetic to animals or are thinkers whose lack of moral sympathy with animals conflicts with claims that are central to these thinkers' philosophies?

nomena and terms, on the other, three options logically exhaust the alternatives, the first two of which have dominated philosophy since Descartes. Either (1) this apparent duality is real, as Descartes suggested - a view which has disastrous consequences for animals - or (2) the mental phenomena and terms can in some way or other be reduced to bodily phenomena or terms - a view which also has disastrous consequences for animals, and perhaps for human beings as well, in that the basic constituents of reality are seen as inert, lifeless, devoid of internal significance. Moral significance arises tenuously only when these mechanical building blocks are configured in certain (often arbitrary) ways, say when they make it possible for a human being eventually to utter propositions. On Richard Rorty's version of this view, moral significance 
does not exist before such utterances can be made. ${ }^{6}$ But it is not often noticed these days that there is a second alternative to dualism. (3) One can attribute (on the grounds provided by several sorts of evidence) some mode of life or activity or form to the constituents even of bodily phenomena, thereby explaining how internal relations, and hence inherent value, are possible. Both (Platonic-Whiteheadian) panpsychism and (Aristotelian-ThomisticPeircian) hylomorphism are versions of this third view, which is not only compatible with, but actually provides the only possible metaphysical foundation for, Tom Regan's theory of inherent value. (I make this suggestion in spite of the fact that Regan himself may not be particularly interested in metaphysical foundations.) After reading the various criticisms of Regan's views, I think it is fair to say that what (unfortunately) bothers most people is not so much that Regan says that animals have inherent value, but that anything has inherent value. It should be noted that hardly any premodern philosopher would criticize Regan on these grounds.

A second reason can also be imagined which would support the broad claim made above regarding the significant gap between Aquinas and Descartes. It is often held that speciesism is due to the Judeo-Christian tradition, and I think that there is some legitimacy to this claim. But the aforementioned gap between Aquinas and many, if not most, postCartesian philosophical treatments of animals should force us to consider seriously the origins of modern speciesism, a speciesism which is intensified by precisely those phenomena in the history of ideas which made their first appearance in the period between Aquinas and Descartes. I speak of a supposedly free market economy and its attendant, an exaggerated metaphysical individualism pos- sessed by human beings, an individualism which actually makes a virtue of amoral selfinterest, if not of selfishness.?

I admit that the two most important defenders of animal rights in recent debates have both been involved in the continuation of intellectual projects started in post-Cartesian philosophy. Singer can be seen as the inheritor of Bentham's and Mill's concern for animals, and Regan's thought can be seen as a (peculiar) elaboration of principles found in Kant and G.E. More. But as a consequence of reading Barad's article, I am more convinced than ever that there is also a great deal to be learned from those contemporary defenders of animal rights who take as their starting points the classics of pre-modern philosophy; in particular I am thinking of Stephen R.L. Clark. ${ }^{8}$ Clark is instructive regarding how the virtuebased approach to ethics can supplement, at the very least, utilitarian and deontological defenses of animals.

It is not my aim to deny any continuity between Aquinas and modern philosophers, say between Aquinas and Kant regarding the

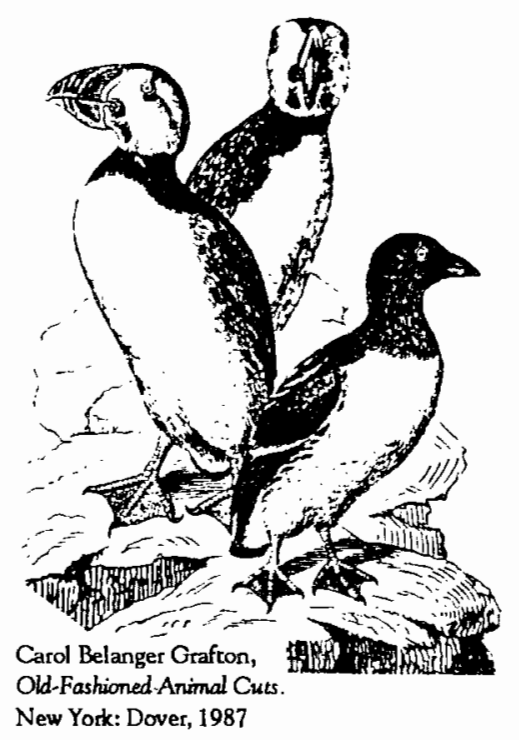


claim that we do not owe respect to animals directly, but only indirectly when they are our neighbor's property. But even here discontinuity should have the upper hand because property, for Aquinas, is legitimate only within the confines of some larger moral or theological purpose, whereas Kant travels a great distance down the road which leads to property as an absolute right for individual human beings. Once again, it is not insignificant to note that between these two thinkers lies the triumph of instrumental reason, of techne over sophia, of animals as industrial (or post-industrial) tools.

I should end, I suppose, by apologizing for not talking about Barad's article directly, but I hope it is clear that what I have said is indirectly connected to her article. It is because Aristotle's and Aquinas' positions regarding animals are so complex that I have suggested that we re-focus our from-to perspectives so as to consider in detail the period from Aquinas to Descartes, in particular, and from pre-modern to modern philosophy, in general.

And I have at least threatened to show in a short space that such a re-focusing would have important consequences for how we should think about the influence of the Judeo-Christian tradition on thought about animals, but more importantly for how we should think about the influence of modern political economy on thought regarding animals and about the contemporary dogma that if Cartesian dualism is untenable then the only alternative is some variety of materialistic monism. Such a re-focusing, I also allege, would allow us to see some worthwhile features of virtue-based ethics not mentioned by Alasdair Macintyre. In short, such a re-focusing of from-to perspective would make defenders of animal rights a bit more eager to become armchair classicists and medievalists.

\section{Notes}

${ }^{1}$ See John Cottingham, " A Brute to the Brutes?': Descartes' Treatment of Animals," Philosophy 53 (1978): 551-559.

2 An in-depth treatment of from-to perspective in history of philosophy can be found in James Collins, Interpreting Modern Philosophy (Princeton: Princeton University Press, 1972).

${ }^{3}$ See Leonora Rosenfield, From Beast-Machine to Man-Machine (N.Y.: Octagon, 1968).

4 On Porphyry's rendering of Theophrastus' position, see my The Philosophy of Vegetarianism (Amherst: University of Massachusetts Press, 1984).

5 If this claim seems too strong, read the abstracts of papers in ethics at any recent American Philosophical Association convention.

${ }^{6}$ See Richard Rorty, Philosophy and the Mirror of Nature (Princeton: Princeton University Press, 1979) and my "Rorty on Pre-Linguistic Awareness in Pigs," Ethics \& Animals 4 (1983): 2-5. Also see my Harthshome and the Metaphysics of Animal Rights (Albany: SUNY Press, 1988).

7 Once again, if this claim seems too strong, see my "Adam Smith's The Theory of Moral Sentiments and Christianity," American Benedictine Review 35 (1984): 422-438.

8 See Stephen R.L. Clark, The Moral Status of Animals (Oxford: Clarendon Press, 1977); “Animal Wrongs," Analysis 38 (1978): 147-149; and The Nature of the Beast: Are Animals Moral? (Oxford: Oxford University Press, 1982).

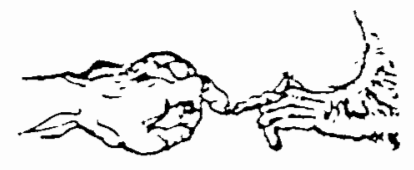

